\title{
Model-based strategy for cell culture seed train layout verified at lab scale
}

\author{
Simon Kern ${ }^{1,2}$, Oscar B Platas ${ }^{1}$, Martin Schaletzky ${ }^{1}$, Volker Sandig ${ }^{3}$, Björn Frahm², Ralf Pörtner ${ }^{1 *}$ \\ From 24th European Society for Animal Cell Technology (ESACT) Meeting: C2P2: Cells, Culture, Patients, Products \\ Barcelona, Spain. 31 May - 3 June 2015
}

\section{Background}

Production of biopharmaceuticals for diagnostic and therapeutic applications with suspension cells in bioreactors requires a seed train up to production scale [1]. For the first steps - the transitions between T-flasks, tubes, roller bottles, shake flasks, stirred bioreactors or singleuse reactors - the experimental effort to lay-out these steps is high. At the same time it is known that the first cultivation steps have a significant impact on the success or failure in production scale. A software tool has been developed which provides possibilities for simulation, analysis and design of seed trains [2]. Tool structure:

- A kinetic model. In this case a simple unstructured model where kinetic parameters can be obtained from a few experiments only.

- A Nelder-Mead-algorithm to determine model parameters.

- A developed MATLAB software tool able to determine optimal points in time or viable cell concentrations for transfer into the next scale.

The successful application for the cell line (AGE1. $\mathrm{HN}_{A A T}$, ProBioGen AG) has been shown previously [3]. Here the tool was tested for a suspendable $\mathrm{CHO}$ cell line.

\section{Materials and methods}

The cell line $\mathrm{CHO}-\mathrm{K} 1$ has been grown in chemically defined TC-42 medium (TeutoCell AG, Bielefeld, Germany), $4 \mathrm{mmol}$ L-1 glutamine.

Data for parameter identification for the kinetic mode were determined in shake flask cultures. The seed train

\footnotetext{
* Correspondence: poertner@tuhh.de

1 Institute of Bioprocess and Biosystems Engineering, Hamburg University of Technology, Hamburg, D-21073, Germany

Full list of author information is available at the end of the article
}

steps were: 1 . culture tube $(0.0025 \mathrm{~L}), 2$. shake flask $(0.070 \mathrm{~L}), 3$ : Labfors 5 Cell (2 L).

\section{Results}

For the seed train first different optimization criteria were compared in silico (Fig. 1a). Finally, the average of time at maximal space-time-yield (STY) and time at $90 \%$ of maximal growth rate $(0.9 \cdot \mu \max )$ was used as optimization criterion for cell transfer. The concept was tested successfully up to a $2 \mathrm{~L}$ scale for 3 scale-up steps (Figure $1 \mathrm{~b}$ ).
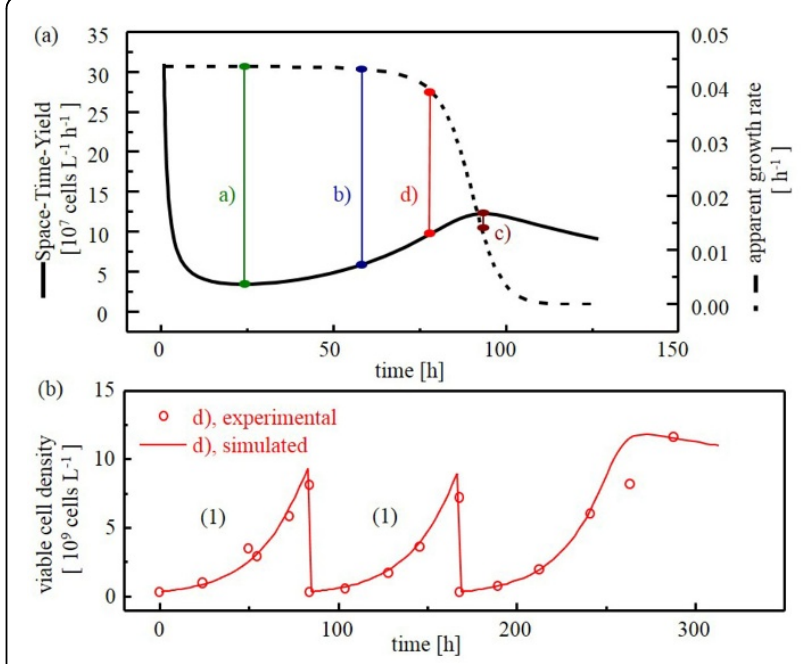

Figure 1 (A) simulated courses of Space-Time-Yield (STY) and apparent growth rateover time exemplarily for one scale: a) point in time of minimal STY, b) average value of a) and c) as a cell passaging criterion, c) point in time of maximal STY as a cell passaging criterion, d) average of time at maximal STY and time at $0.9 \cdot \mu_{\max }$ as a cell passaging criterion. (B) Seed train for CHO-K1 - simulated and experimental courses of viable cell density over time. Passaging of cells at the points in time calculated using average of time at maximal STY and time at $0.9 \cdot \mu_{\max }$ (criterion d)).The seed train steps were: 1. culture tube $(0.0025 \mathrm{~L})$, 2. shake flask $(0.070 \mathrm{~L}), 3$ : Labfors 5 Cell $(2 \mathrm{~L})$ 


\section{Conclusions}

The concept offers a simple and inexpensive strategy for design of seed train scale-up steps. The results for the lab scale steps show that the tool was able to perform a seed train optimization only on the basis of two batches, the underlying model and its parameter identification.

\section{Acknowledgements}

The bioreactor (Labfors 5 Cell) was kindly provided by the company Infors AG, the suspendable cell line CHO-K1 by Prof. Thomas Noll, University of Bielefeld.

\section{Authors' details}

${ }^{1}$ Institute of Bioprocess and Biosystems Engineering, Hamburg University of Technology, Hamburg, D-21073, Germany. ${ }^{2}$ Biotechnology \& Bioprocess Engineering, Ostwestfalen-Lippe University of Applied Sciences, Lemgo, D-32657, Germany. ${ }^{3}$ ProBioGen AG, Berlin, D-13086, Germany.

Published: 14 December 2015

\section{References}

1. Eibl R, Eibl D, Pörtner R, Catapano G, Czermak P: Cell and Tissue Reaction Engineering. Springer 2008, ISBN 978-3-540-68175-5.

2. Kern S, Platas-Barradas O, Pörtner R, Frahm B: Model-based strategy for cell culture seed train layout verified at lab scale. Cytotechnol, published online: 21 March 2015, DOl 10.1007/s10616-015-9858-9.

3. Kern S, Platas O, Schaletzky M, Sandig V, Frahm B, Pörtner R: Model-based design of the first steps of a seed train for cell culture processes. $B M C$ Proceedings 2013, 7(Suppl 6):P11, (4 December 2013).

\section{Submit your next manuscript to BioMed Central} and take full advantage of:

- Convenient online submission

- Thorough peer review

- No space constraints or color figure charges

- Immediate publication on acceptance

- Inclusion in PubMed, CAS, Scopus and Google Scholar

- Research which is freely available for redistribution

Submit your manuscript at www.biomedcentral.com/submit
Ciomed Central 